\title{
高密度ポリエチレンのブローアップ成形過程で 生ずる線膨張係数の分布特性
}

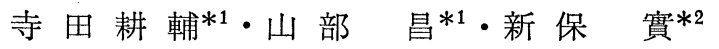 \\ 宮野 靖*2 ・ 梶原稔尚*3 ・船津 和 守*4
}

\section{Mechanism of HDPE Thermal Expansion Coefficient Distributions during Blow-up Process}

\author{
Kousuke Terada*1, Masashi Yamabe*1, Minoru Shimbo*2 \\ Yasushi Miyano*2, Toshihisa Kajiwara*3, Kazumori Funatsu*4
}

\begin{abstract}
The shrinkage degree $\xi$ of polymer products must be considered when the molds are at the stage of designing. On the calculation of $\xi$, the descending temperature $\Delta T$ of polymer products after molding process and $\alpha$ (thermal expansion coefficient in polymer products) are necessary. It was found that $\alpha$ has the typical distributions at the various layers along the machine direction (MD) and the transverse direction (TD), especially HDPE products. Consequently, $\alpha$ distributions should be prodicted for estimation of accurate $\xi$ of HDPE products.

The blow molding process is divided into the following two processes.
(a) Parison extrusion process
(b) Blow-up process

We reported the previous paper that $\alpha_{P}$ (thermal expansion coefficient in parison) distributions correspond to the strain distributions under extrusion process. In this study, we have investigated the experimental data of $\alpha$ distributions after blow-up process and calculated the elongational strain in deforming parison by analysis using finite element method. The following results were obtained.

(1) The measured data of $\alpha$ in products correspond to that of $\alpha_{\mathrm{P}}$ which gets the reduction by the elongational strain during blow-up process

(2) We proposed the model equation of relationship between $\alpha_{\mathrm{P}}$ and $\alpha$. The model equation expressed the characteristic of measured data of $\alpha$ in this study.
\end{abstract}

Key words : HDPE/Blow-up process/Finite element method/Thermal expansion coefficient $/$ Shrinkage degree

*1 日産自動車(株) 技術開発センター

厚木市岡津古久 560-2 (宁243-01)

Simultaneous Engineering Center

Nissan Motor Co., Ltd.

560-2 Okatsukoku, Atsugi, Kanagawa 243-01 Japan

*2 金沢工業大学 材料システム工学科

石川県石川郡野々市町扇が丘 7-1 (テ921)

Department of Mechanical System Engineering

Kanazawa Institute of Technology

7-1, Ohgigaoka, Nonoichi, Ishikawa-gun, Ishikawa 921 Japan

*3 九州工業大学 工学部 物質工学科

\section{北九州市戸烟区仙水町1-1（宁804）}

Department of Materials Science and Engineering

Kyushu Institute of Technology

1-1 Sensuimachi, Tobata-ku, Kitakyushu, Fukuoka 804 Japan

*4 九州大学 工学部 化学機械工学科

福岡市東区箱崎6-10-1 (宁812)

Department of Chemical Engineering

Kyushu University

6-10-1 Hakozaki, Higashi-ku, Fukuoka 812 Japan 1995. 10.6 受理 
Table 1 Dimensions of the dies

\begin{tabular}{l|c|c}
\hline Type of die & $\begin{array}{c}\text { Diverged } \\
\text { die }\end{array}$ & $\begin{array}{c}\text { Converged } \\
\text { die }\end{array}$ \\
\hline $\begin{array}{c}\text { Outer diameter at the } \\
\text { die exit } 2 R_{\mathrm{o}}(\mathrm{mm})\end{array}$ & 400 & 220 \\
$\begin{array}{c}\text { Inner diameter at the } \\
\text { die exit } 2 R_{\mathrm{i}}(\mathrm{mm})\end{array}$ & 390 & 210 \\
Die gap $R_{\mathrm{o}}-R_{\mathrm{i}}(\mathrm{mm})$ & 5 & 5 \\
\hline
\end{tabular}

\section{1. 緒言}

樹脂成形品は, 成形終了時に離型され, 成形品温度 が降下することによって収縮現象が生ずるため, 成形 用金型設計段階に抢いて成形品収縮量を考慮する必要 がある. 収縮量は, 収縮率と成形品形状寸法から計算 でき, 収縮率は, 降下温度と線膨張係数から設定され る. このうちの線膨張係数は, 成形での流動過程で生 ずる配向のために異方性が多くの場合飞認められ，予 測が困難な物性值である。 しかし, 成形品形状精度が その用途によって重要となる場合には, 設計段階で設 定した収縮率と実際の成形品収縮率との誤差の発生は, 部品開発に和いて問題となる.

著者らは, 熱可塑性樹脂である高密度ポリエチレン (HDPE) をブロー成形材料とする樹脂製ガソリンタ ンク成形品収縮量の予測精度向上のために, 成形品線 膨張係数分布発生の要因を解明し，線膨張係数分布を 材料物性と成形条件から予測する研究を進めている.

ブロー成形法は, パリソン押出過程, ブローフップ 成形過程, 金型内冷却過程に大きく分けられ, 前報1) では, 押出過程でのダイ内流動過程に着目して実験と 解析から流れ方向 (以下 $\mathrm{MD}$ 之略す) とその直角方向 (以下 TD と略す)各々の肉厚方向に括沙る線膨張係数 分布を把握し, ダイ内流解析を行い, 分布発生の要因 を検討した. その結果, ダイ内流動過程で生ずる伸長 ひず久分布と線膨張係数分布とが相関関係を有するこ とを示した.

本報では, 押出後のパリソンの線膨張係数を初期值 とし, ブローアップ成形過程での線膨張係数の变化を 実験から求めて, 成形品線膨張係数分布予測手法を検 討した内容について報告する.

\section{2. 線膨張係数の測定と測定結果}

\section{1 線膨張係数の測定}

成形品線膨張係数分布を把握するため, 次の方法で, 成形品からサンプルを採取し, 試験片を作成して線膨 張係数 $の$ の測定を行った.
Table 2 Dimensions of the tank

\begin{tabular}{c|c}
\hline & $\begin{array}{c}\text { Dimensions } \\
(\mathrm{mm})\end{array}$ \\
\hline$X$ & 900 \\
$Y$ & 540 \\
$Z$ & 260 \\
\hline
\end{tabular}

\section{a. 試験片作成}

大型ブロー成形機に Table 1 に示した種類のダイを 搭載し, 約 $200^{\circ} \mathrm{C}$ で押し出したパイプ状の溶融樹脂 (パリソン) に空気を吹き込み, Table 2 の形状寸法の タンクを成形した. Fig. 1 亿示した例のように，サン プルを $\mathrm{MD}, \mathrm{TD}$ 各々から採取した。採取した部位と その選定理由は，次のと扮りである。

(1) パリソン初期肉厚は, 約 $10 \mathrm{~mm}$ 程度であるが, 成形品肉厚は，ブローアップによる伸長变形量の 度合に応じて肉厚に分布が生ずるため, 約 3.0 8. $0 \mathrm{~mm}$ 程度となる.

成形品肉厚分布の $\alpha$ への影響を検討するため, ダイバージ型ダイを用いて成形したタンクの肉厚 3. $0,5.0,8.0 \mathrm{~mm}$ の 3 個所の部位から $\mathrm{MD}$, TD のサンプル 6 つ $(3 \times 2)$ を採取し, 試験片 No. 1 6 (肉厚 $\times$ 幅 $5 \mathrm{~mm} \times$ 長さ $15 \mathrm{~mm}$ 程度)を作成した. 成形品は曲面を有するため, 直線状のサンプルと しては長さが $15 \mathrm{~mm}$ 程度となった。

(2) 次に，ダイ形状の成形品 $\alpha$ への影響を検討する ため,コンバージ型ダイを用いて成形したタンク

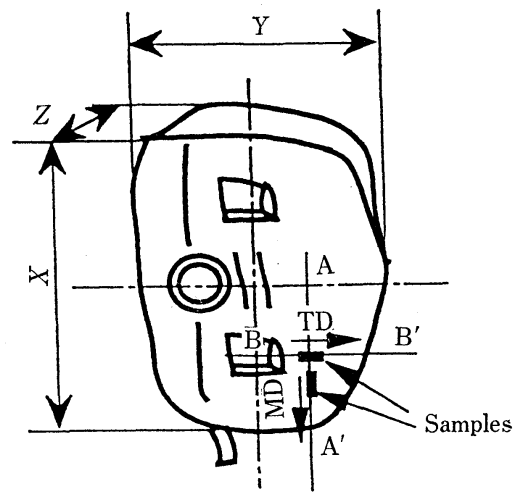

(a) Sampling from the tank

Outside of the part

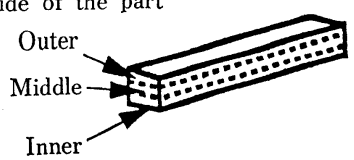

Inside of the part

(b) 3 layers of samples

Fig. 1 Preparation of samples from the tank for thermal expansion measurement 
の平均的な肉厚 $6 \mathrm{~mm}$ 程度に拈ける部位から $\mathrm{MD}$, TD のサンプル 2 つを採取した．このサンプルは， 成形品の平坦部から採取できたため, 直線状のサ ンプル長さとして約 $50 \mathrm{~mm}$ 程度確保した. これ ら 2 つのサンプルの厚さ方向の $\alpha$ 分布を検討する ため, 3 つの層（外層, 中間層, 内層）に分離し, 各層から試験片 No. 7 12(約 $0.2 \mathrm{~mm} \times 10 \mathrm{~mm} \times$ $50 \mathrm{~mm}$ ) 程度を切り出した.

\section{b $\boldsymbol{\alpha}$ 測定方法}

試験片サイズによって，取り扱いの容易さが異なる ため, 次のように 2 種類の測定方法で $\alpha$ を求めた.

(1) 試験片 No.1 6

試験片サイズが小さいので取扱性が良くないため, T.M.A（接触式変位測定装置）で昇温（常温から 100 ${ }^{\circ} \mathrm{C}$ まで $2{ }^{\circ} \mathrm{C} /$ 分）をに拈ける長さ変化を測定し， $\alpha$ を求 めた.

\section{(2) 試験片No. 7〜12}

試験片サイズが大きいため, 取扱性が良く, 昇温・ 降温（常温から $100^{\circ} \mathrm{C}$ む゙ $2^{\circ} \mathrm{C} /$ 分）を 3 回繰り返しア ニール処理後, 昇温時および降温時において非接触電 子光学変位測定装置により長さ変化を測定して, 同条 件での 2 回の測定データの平均から， $\alpha$ を求めた.

以上による測定方法から得られた結果を, Figs. 2 4 に示した。

\section{2 線膨張係数の分布特性}

測定から得られた $\alpha$ 分布特性は, 次のと抏りである.

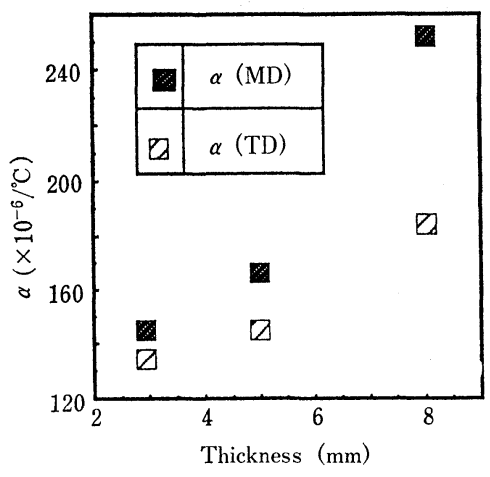

Fig.2 Measured data of $\alpha$-thickness for the diverged die

また，本報で， $\alpha$ と比較するために用いた成形の前段 階に抢壮るパリソンの線膨張係数測定結果（以下 $\alpha_{\mathrm{P}}$ と略す)は，前報1から引用した。

\section{a. 成形品肉厚の影響}

Fig. 2 の測定結果から, 肉厚の薄い部位ほど伸長変 形量を大きく受け，その伸長変形量に応じて $\alpha か ゙$ 低下 していることが示された。 また，前報で示したダイバ 一ジ型ダイからの $\alpha_{\mathrm{P}}$ の特徵である $\alpha_{\mathrm{P}}(\mathrm{MD})>\alpha_{\mathrm{P}}$ (TD) の関係が，成形品 $\alpha$ に扮いても各肉厚部位て保 たれている.

\section{b・ダイ形状の影響}

コンバージ型拈よびダイバージ型ダイ各々の成形品

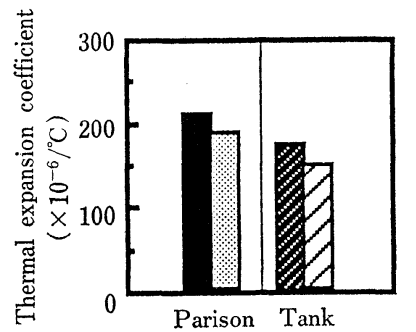

(a) Diverged die

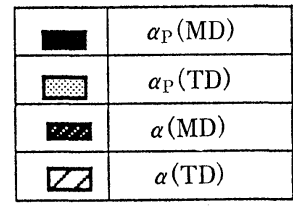

Fig.3 Measured data of $\alpha_{\mathrm{P}}(\mathrm{MD}), \alpha_{\mathrm{P}}(\mathrm{TD}), \alpha(\mathrm{MD}), \alpha(\mathrm{TD})$

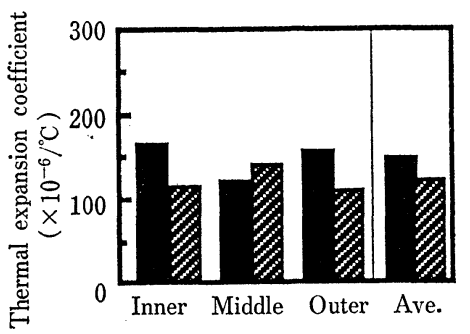

(a) $\alpha_{\mathrm{P}}(\mathrm{MD})$ and $\alpha$ (MD)
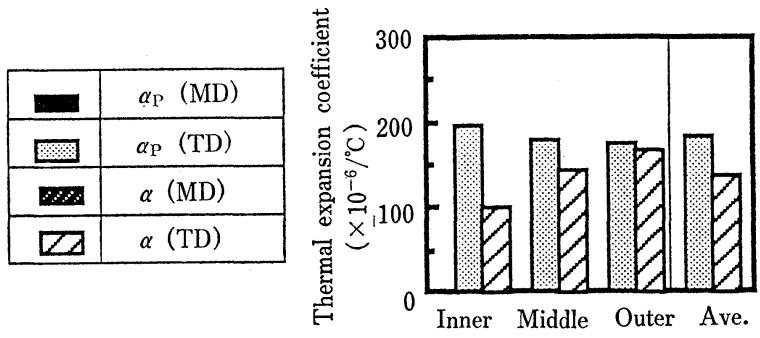

(b) $\alpha_{\mathrm{P}}$ (TD) and $\alpha$ (TD)

Fig.4 Measured data of $\alpha_{\mathrm{P}}(\mathrm{MD}), \alpha_{\mathrm{P}}(\mathrm{TD}), \alpha(\mathrm{MD}), \alpha(\mathrm{TD})$ distributions for the converged die 


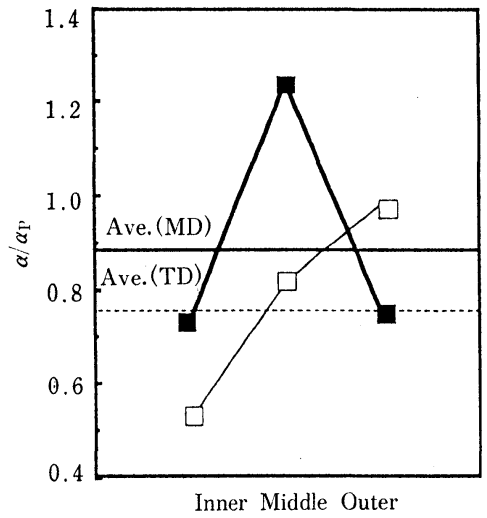

Fig.5 $\alpha / \alpha_{\mathrm{P}}$ distribution for the converged die ( $: \mathrm{MD}, \square: \mathrm{TD}$ )

の平均的肉厚 $5 \sim 6 \mathrm{~mm}$ 部位に和ける $\alpha(\mathrm{MD}), \alpha(\mathrm{TD})$ と, 前報で示した成形前のパリソン $\alpha_{P}(M D), \alpha_{P}$ (TD)をFig. 3 に示した。これらから， $\alpha$ (MD) と $\alpha$ (TD) の大小関係は, 成形前拈よび成形後において も保持されている。すなおち，

(1) ダイバージ型の場合

$\alpha_{\mathrm{P}}(\mathrm{MD})>\alpha_{\mathrm{P}}(\mathrm{TD})$ から $\alpha(\mathrm{MD})>\alpha(\mathrm{TD})$

(2) コンバージ型の場合

$\alpha_{\mathrm{P}}(\mathrm{MD})<\alpha_{\mathrm{P}}(\mathrm{TD})$ かつ $\alpha(\mathrm{MD})<\alpha(\mathrm{TD})$

となる。

以上から, 成形品 $\alpha$ は, ブローアップ成形過程の前 段階の $\alpha_{\mathrm{P}}$ が初期值となり，ブローアップでの伸長変 形によって $\alpha_{\mathrm{P}}$ が低下した分布になっていることが示 された。

\section{c . $\alpha(M D)$ ¿ $\alpha(T D)$ の層分布}

Fig. 4 亿示した測定結果から,ブローアップ成形過 程での各層に和沙る成形前後の $\alpha$ 変化率を計算し,

Fig. 5 に示した. 層分布の変化の特徵は, 次のと拈り である。

(1) 成形品 $\alpha(\mathrm{MD})$ 層平均值は, $\alpha_{\mathrm{P}}(\mathrm{MD})$ 層平均 值に比較して，約 $12 \%$ 程度低下している.

(2) 成形品 $\alpha(\mathrm{TD})$ 層平均値は, $\alpha_{\mathrm{P}}(\mathrm{TD})$ 層平均値

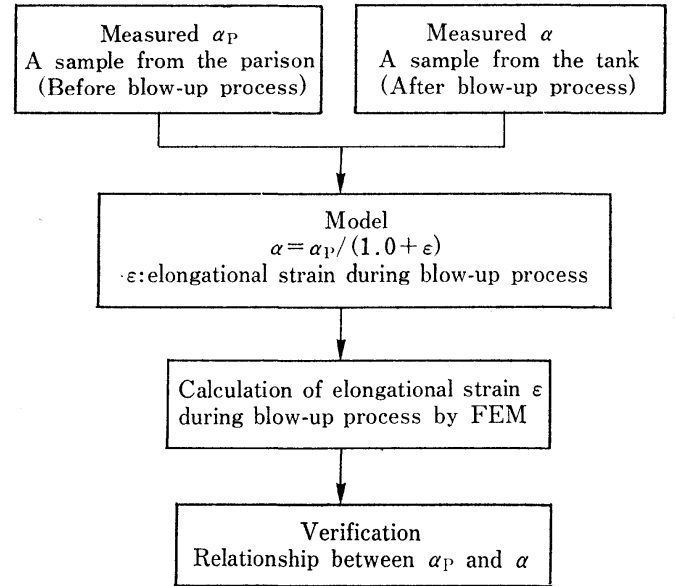

Fig.6 Flow chart of investigation in this study

に比較して, 約 $24 \%$ 程度低下している.

(3) 3 層間における $\alpha_{\mathrm{P}}(\mathrm{MD})$ は凹分布であるが， 成形品 $\alpha(\mathrm{MD})$ では均一な分布（やや凸分布）に 移行している。

(4)これに対して，3 層間に㧍ける $\alpha_{\mathrm{P}}$ (TD)はほぼ 均一な分布であるが，成形品 $\alpha$ (TD) では内層側 が大きく低下した分布となっている.

\section{3. 成形品 $\alpha$ 分布予測}

前章では, ブローアップ成形過程の前段階に括忷る パリソンから採取したサンプルの線膨張係数 $\alpha_{\mathrm{P}}$ とブ ローアップ成形過程を経たタンク成形品から採取した サンプルの線膨張係数 $\alpha$ の測定結果について述べた.

これらの結果から，ブローアップ成形過程に执いてパ リソンが受ける伸長変形量に応じ， $\alpha_{\mathrm{P}}$ を初期值とし てんが低下する特性を明らかにした。

本章では，ブローアップ成形過程前後に拈ける線膨 張係数の变化を定量的洘察し, 成形品 $\alpha$ 分布予測手 法を提案する.

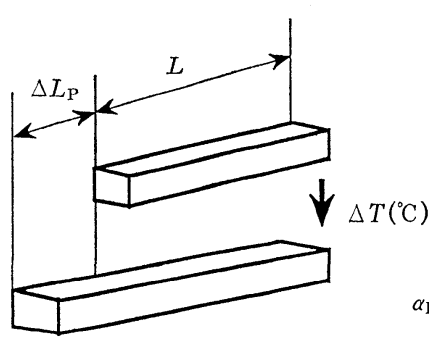

(a) A sample from the parison

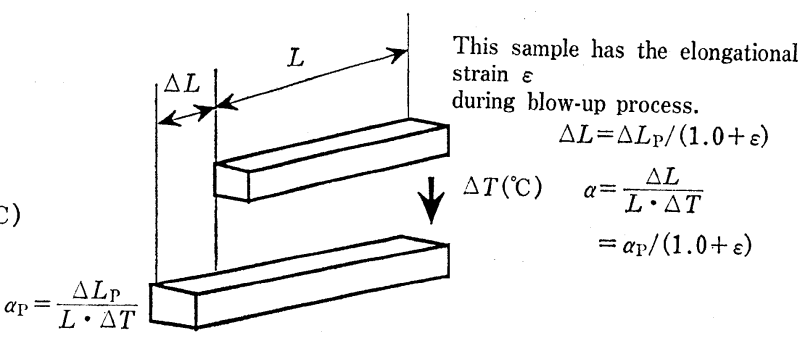

(b) A sample from the tank

Fig.7 Model (The relationship between $\alpha_{\mathrm{P}}$ and $\alpha$ is $\alpha=\alpha_{\mathrm{P}} /(1.0+\varepsilon)$ ) 


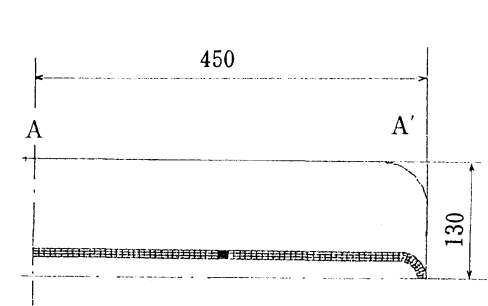

(a) Section A-A' (MD)

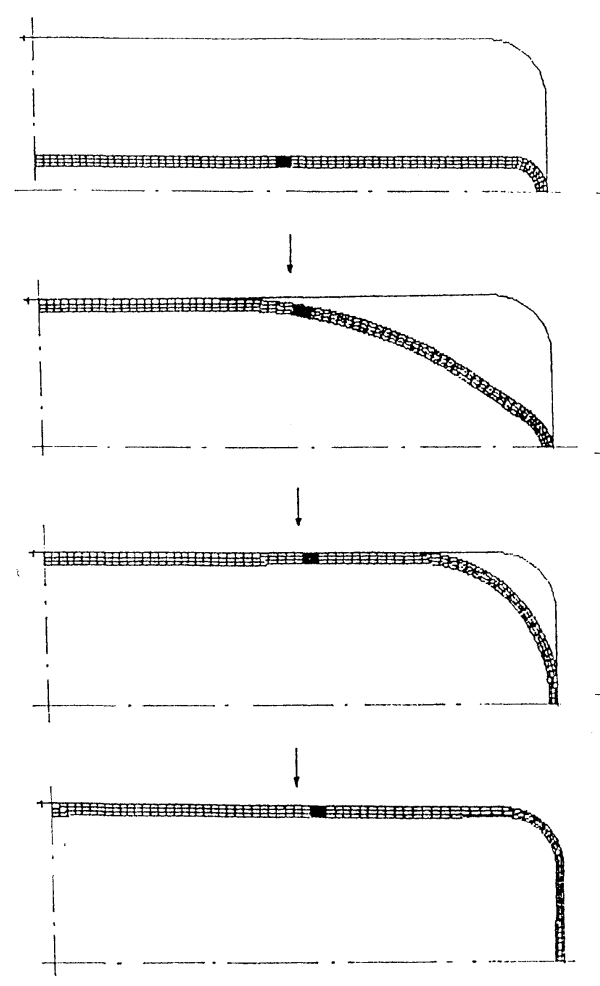

(a) $\mathrm{MD}$

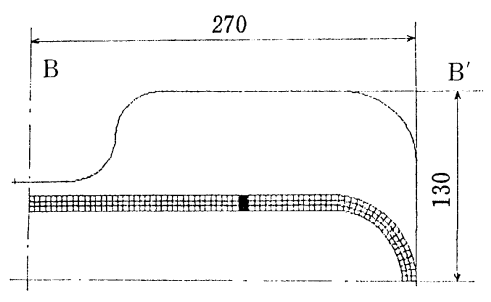

(b) Section B-B' (TD)
Fig.8 Shape of section $\mathbf{A}-\mathbf{A}^{\prime}$ and $\mathbf{B}-\mathbf{B}^{\prime}$
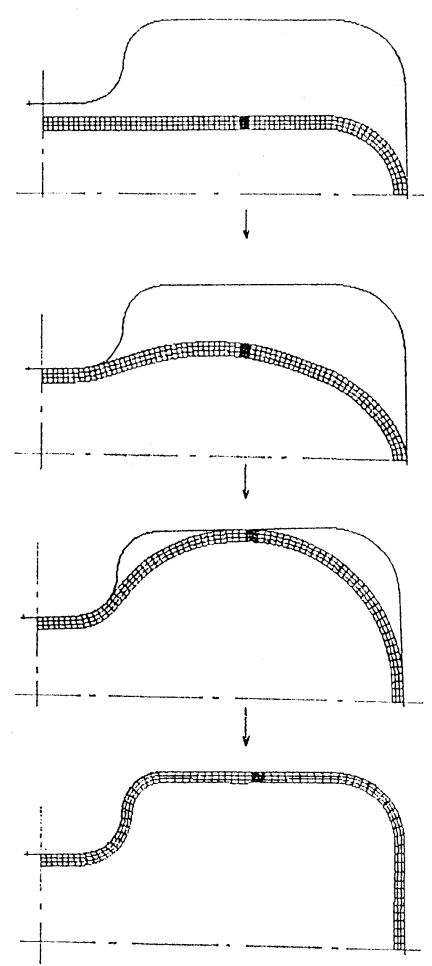

Fig.9 Blow molding simulation

\section{$3.1 \alpha_{\mathrm{P}}$ と $\alpha$ の関係}

ここでの $\alpha_{\mathrm{P}}$ と $\alpha$ の関係についての検討手順を,

Fig. 6 のフローチャートに示した. 本報で提案するモ デルは，ブローアップ成形過程での力学的なひずみと 温度変化による熱的な負荷から発生するひずみが高分 子構造に与学る影響は同等であるといら仮定を扣いて いる.すなわち, 力学的に伸長される場合と熱膨張に より伸長される場合も同様に高分子構造が引き揃光ら れると考えている.

この仮定のもとに，線膨張係数測定時に和けるサン プルの長さ変化の挙動を, 模式的にFig. 7 に示した. ブローアップ成形過程の前段階でのパリソンからのサ ンプルに対して，ブローアップ成形過程を経たタンク 成形品からのサンプルは, 温度変化 $\Delta T$ を受けた場合, その長さ変化は異なる。

(b) $\mathrm{TD}$

各サンプル長さを $L$, パリソンからのサンプルの長 さ変化を $\Delta L_{\mathrm{P}}$, 成形品からのサンプルの長さ変化を $\Delta$ $L$ とすると，次式が成り立つ.

$$
\begin{aligned}
& \alpha_{\mathrm{P}}=\Delta L_{\mathrm{P}} /(\Delta T \times L) \\
& \alpha=\Delta L /(\Delta T \times L)
\end{aligned}
$$

成形品からのサンプルが，ブローアップ成形過程に おいて伸長ひずみをを受けており, 温度変化が起こる 前の状態に沶いて，高分子材料としてすでに みをもっていたとし, 次の関係が近似的に成り立つと 仮定する.

$$
\Delta L=\Delta L_{\mathrm{P}} /(1.0+\varepsilon)
$$

すなわち,

$$
\alpha=\alpha_{\mathrm{P}} /(1.0+\varepsilon)
$$

である。

次に,ブローアップ成形過程での伸長ひずみをを計 


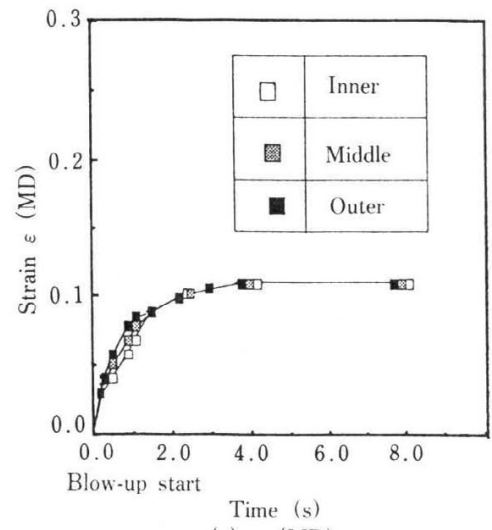

(a) $\varepsilon(\mathrm{MD})$

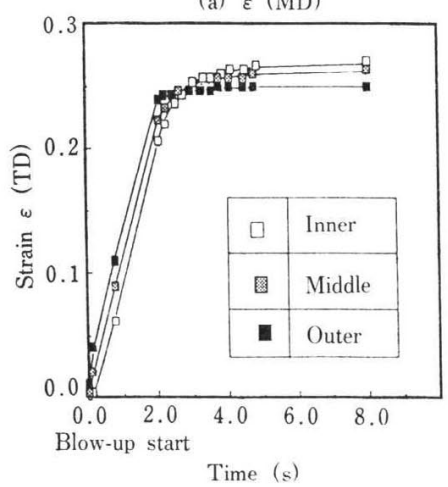

(b) $\varepsilon(\mathrm{TD})$

Fig.10 $\varepsilon(M D)$ aud $\varepsilon(T D)$

算し, 測定結果の $\alpha_{\mathrm{P}}$ と $\alpha$ が, 提案されたモデルの （4）式を満たすかを検䛧する.

\section{2 ブローアップ成形過程での伸長ひずみ $\varepsilon$ の計 算}

検証のための $\boldsymbol{\alpha}$ 測定結果として, 非接触電子光学変 位測定装置から求めた Fig. 4 のデータを対象とした。 成形品からこれらの試験片を採取した部位に拈ける $\mathrm{MD}, \mathrm{TD}$ の各断面は, Fig. 8 に示した $\mathrm{A}-\mathrm{A}^{\prime}$ 断面とB$\mathrm{B}^{\prime}$ 断面である. $\mathrm{MD} に つ い て ~ A-A^{\prime}$ の断面には凹凸 がないが，TDについてのB-B'断面には凹凸がある。 ブローアップによりパリソンが受ける伸長ひずみ分 布を, 有限要素法 (FEM) に上る汎用構造解析用プロ グラム (ABAQUS) を用いて, 次の要領で計算した。

(1) 各断面の初期パリソン形状を, Fig. 8 と示すよ らに，8節点平面ひずみ要素を用いた 3 層構造体 として要素と節点でモデル化した。

(2) 空気圧の上昇によるブローアップ現象を，構成 した要素の内層面に作用する分布荷重として表し， 荷重增分法で解析した。

(3) 構成した要素の材料モデルは, 弾性体とした。 Young 率を溶融 HDPE の引張試験から約 $1.0 \times$
$10^{6}(\mathrm{~Pa})$ とし, Poisson 比を 0.45 とした2).

(4) パリソン変形後, 金型に接触した要素は金型上 を滑らないと仮定した2)

(5) 解析結果として, 要素が伸長変形を受けること によって発生する伸長ひずみ分布を出力させた．

(6)ひず文速度を評価する際には，ブローアッブが 終了するのに要する時間として, 成形過程に和け る金型空気出口压測定から約 $10 \mathrm{~s}$ とした。

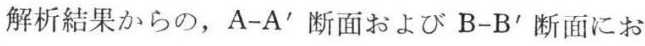
けるパリソンの変形図（着色部はサンプル採取個所で ある）をFig. 9 に，サンプル採取部位に該当する 3 層 の要素のひずみ履歴の計算結果を Fig. 10 に示した。

\section{$3.3 \alpha(\mathrm{MD})$ についての検証}

(1) ブローアップ開始〜 $2 \mathrm{~s}$ に扔いて，一時的に外 層側が内層側上りもひずみが大きくなる。この理 由は, パリソンの変形図からわかるように, 膨張 するパリソンの外側ほどひずみ増分が大きいため である。

(2) しかし，4 s 以降に批いて各層のひずみの計算 結果は, 約 0.11 程度で均一となっている.この ため, 成形前の段階であるパリソンでは $\alpha_{\mathrm{P}}(\mathrm{MD})$ に分布が存在したが, ブローアップ成形過程後に おいてほぼ均一な分布 $\alpha(\mathrm{MD})$ となるよらに変化 したと考兄られる。

(3) $\alpha_{\mathrm{P}}(\mathrm{MD})$ 層平均值は, 成形後において約 $12 \%$ 程度低下している。すなわち, 測定結果では, $\alpha_{\mathrm{P}}$ (MD) と $\alpha(\mathrm{MD})$ の関係は, 次式で表される.

$$
\alpha(\mathrm{MD})=\alpha_{\mathrm{P}}(\mathrm{MD}) \times 0.88
$$

これに対して, 各層が成形過程に捛いて受けるひず み $\varepsilon(\mathrm{MD})$ の計算結果の層平均值は 0.11 である. $\varepsilon$ (MD)を提案したモデルの(4)式に代入すると(6)式 となり, 測定結果 ( 5 ) 式と良く一致することが示され た.

$$
\begin{aligned}
\alpha(\mathrm{MD}) & =\alpha_{\mathrm{P}}(\mathrm{MD}) /(1.0+\varepsilon(\mathrm{MD})) \\
& =\alpha_{\mathrm{P}}(\mathrm{MD}) /(1.0+0.11) \\
& =\alpha_{\mathrm{P}}(\mathrm{MD}) \times 0.90
\end{aligned}
$$

\section{$3.4 \alpha(\mathrm{TD})$ についての検証}

(1) ブローフップ開始 〜 $2 \mathrm{~s}$ において, 一時的に外 層側が内層側よりもひずみが大きくなる。これは， 先に述べた $\alpha(\mathrm{MD})$ の場合の理由と同様である.

(2) しかし， $2 \mathrm{~s}$ 以降に拈いて各層のひず分布の 大きい順位は，逆転現象を起こす。すなわち、ひ ずみの大きい順位は，外層>中間層>内㬝から， 外層<中間層<内層に移行する.

この理由は, Fig. 9(b) に示したように, 金型 上に外層の要素が接触した後も, 断面形状に凹凸 があるため，金型の両コーナー部へパリソンは膨 


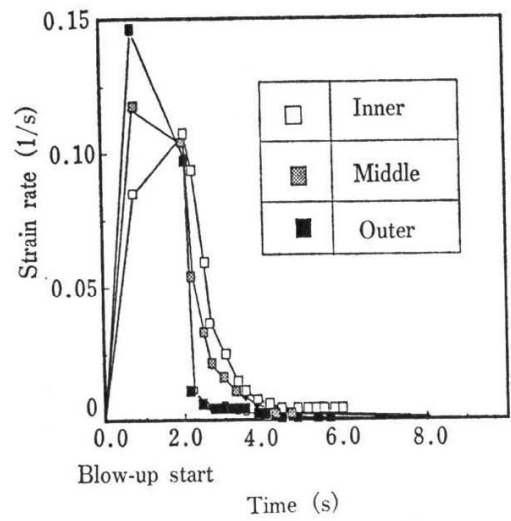

Fig.11 Strain rate (TD)

張し，その結果，金型に接触した部分の内層側の 要素はさらに伸長ひず久を受けるからである。

(3)この現象は, Fig.11 に示したよらに，ひずみ 速度の変化からも説明できる。すむおも，外層の 要素のひずみ速度は, $2 \mathrm{~s}$ 以降注湾零であるが, 内層側の要素には $4 \mathrm{~s}$ 程度までもひずみ速度が発 生している.

(4) したがって, 成形品 $\alpha$ (TD) 分布は, ブローア ップ成形過程に打いて内層側が伸長変形を多く受 けるため，内層側が大きく低下するように変化し たと考えられる。

(5) $\alpha_{\mathrm{P}}$ (TD) 層平均值は，成形後に括いて約 $24 \%$ 程度低下している。すなわち, 測定結果では, $\alpha_{\mathrm{P}}$ (TD) と $\alpha(\mathrm{TD})$ の関係は, 次式で表される.

$$
\alpha(\mathrm{TD})=\alpha_{\mathrm{P}}(\mathrm{TD}) \times 0.76
$$

これに対して, 各層が成形過程において受ける ひずみ $\varepsilon(T D)$ の計算結果の層平均值は，0.26で ある. $\varepsilon(T D)$ を提案したモデルの (4) 式に代入 すると ( 8 )式となり, 測定結果 $(7)$ 式と良く一致 することが示された。

$$
\begin{aligned}
\alpha(\mathrm{TD}) & =\alpha_{\mathrm{P}}(\mathrm{TD}) /(1.0+\varepsilon(\mathrm{TD})) \\
& =\alpha_{\mathrm{P}}(\mathrm{TD}) /(1.0+0.26) \\
& =\alpha_{\mathrm{P}}(\mathrm{TD}) \times 0.79
\end{aligned}
$$

以上から，樹脂製ガソリンタンク成形材料グレード である HDPE がブロー成形される条件範囲において 提案したモデルの(4)式が成り立つことが示された。 ここで, 成形温度条件の影響も考えられるが, 本報で は, HDPE を用いたブロー成形の実用性の観点から, 成形温度域を約 $200^{\circ} \mathrm{C}$ 程度に限定した。 その温度域よ
りも低い場合も高い場合も，次の理由により実用的で ないからである。

(1) 低い温度域

成形材料 HDPE の延伸性が低下して成形しにくく なる.

(2) 高い温度域

成形材料 HDPE が熱劣化しやすくなる.

な和，成形品 $\alpha(\mathrm{MD}), \alpha(\mathrm{TD})$ の層平均值分布を物 性データとし, 有限要素法の構造解析による収縮シミ ュレーションを行らことによって，金型設計のための 収縮率分布を設定することができる。

\section{5. 結言}

ブローアップ成形過程に招いて生ずる線膨張俰数の 分布特性とその発生要因について検討孝行い，次の結 論を得た。

(1) 測定結果から, 成形品 $\alpha(\mathrm{MD}), \alpha$ (TD)の各々 の層平均值は, 成形の前段階であるパリソン $\alpha_{\mathrm{P}}$ (MD)， $\alpha_{\mathrm{P}}(\mathrm{TD})$ からブローアップ成形過程での 伸長ひずみに応じて低下することが示された。

(2) 力学的なひずみと温度変化による熱的な負荷か ら発生するひずみとが高分子構造に与える影響は 同等であると仮定したモデルを提案し，このモデ ルから導いた $\alpha_{\mathrm{P}}$ と $\alpha$ の関係式を, 本報での実験 条件において成り立つことを示し, 定量的に評価 できた

(3) 今後の課題としては, ここで得られた結論のさ らなる検証と, 成形品 $\alpha$ の層分布に対寸る冷却速 度, 結晶化度およびアニール処理の影響を検討す ることなどがあげられる。

\section{参 考 文 献}

1）寺田耕輔, 山部 昌, 新保 實, 宮野 靖, 梶原 稔尚, 船津和守: 成形加工, 7 (9), 568 (1995)

2) 寺田耕輔, 山部 昌: 成形加工 '89, 129 (1989)

3) de Lorenzi, H.C. and Nied,H.F.: Finite Element Simulation of Thermoforming and Blow Molding, in: Progress in Polymer Processing, Isayev, A.I. (Ed.), 157 (1991), Hanser

4) 田中 太, 中野 亮, 田中豊喜：成形加工, 4( 9 ), 245 (1991)

5）今村伸二, 金田 勉, 九島行正, 大田彰, 戸来 䅮雄, 小山清人：成形加工，6 (11)，797（1995） 